\title{
The Effect of Green Brand Knowledge and Trust on Consumers' Purchasing Intention: The Mediation Role of Attitude Towards Green Brands Egypt Case ${ }^{1}$
}

Ahmed Ragab Sayed

Teaching Assistant

Ahmedragab1993@aast.edu

\section{Dr. Niveen Mohamed El Saghier}

Associate Professor

niveenmohamed@yahoo.com

\author{
Dr. Heba Hassan Sadek \\ Lecturer of Marketing \\ hebahassan@aast.edu
}

\section{College of Management \& Technology- Arab Academy for Science Technology \& Maritime Transport}

\begin{abstract}
Recently, eco-friendly brands $(E F)$ have received considerable attention from companies that seek for the competitive advantage. Growing concerns from governmental and nongovernmental organizations (NGO) and the increase of consumer awareness are reasons why companies are going for environmentally friendly (green) products. despite the importance of this issue, there is a lack of research in testing the impact of green brand knowledge \& green brand trust on Egyptian consumers' green purchasing intentions via attitude towards green brands. So, in order to achieve this objective, three main research questions have been examined. This research was carried out in the Egyptian food \& beverage market sector from the customer perspective, the data were collected only in Cairo, Alexandria, and Aswan, as non-probability convenience sampling technique was used. the country's capital and two of its major cities and the city that attract investors in upper of Egypt and named as the capital of the youth in the African continent, in addition the population density in those cities is high, also, the number of malls and hypermarkets and the density of frequent customers is more in those cities. These questionnaires were analyzed by using (SPSS) to test and analyze the research hypotheses. Findings showed that there's a significant positive indirect impact of green brand knowledge on consumers' green
\end{abstract}

\footnotetext{
${ }^{1}$ Received in 22 March 2021, accepted in 2 August 2021.
} 
purchasing intention via attitude towards green brands. In addition, there's a significant positive direct impact of green brand trust on consumers' green purchasing intention.

Keywords: Green knowledge, Green trust, Attitude towards green brands, Green purchasing intention, Alexandria, Cairo, Aswan, Egyptian food and beverage market.

\section{1- Introduction}

In today's competitive business environment, consumers are looking for the well-known brands having quality which satisfies their needs. In addition, most people belief to protect the environment as they value it. As the international impact on environmental-related issues, such as the impact of waste on the environment, has increased, international environmental protection agencies have formulated successive regulations and launched environmental labels for use in most countries globally (Yang \& Zhao, 2019). Environmental interest has become prevalent for many companies wishing to develop ecological opportunities (Chen \& Chang, 2012). This new perspective has strengthened consumers' needs \& wants to get products that match with this awareness \& way of thinking (Curvelo et al., 2019). Thus, the trend of green marketing has increased in the form of past decades (Hashim et al., 2020). Many people believe that green marketing refers to the promotion or advertising of products with environmental characteristics only, especially in its purchasing decision this kind of products. Green or environmental marketing also refers to environmental green products such as healthy food, recyclable products and environmentally friendly products. Green marketing is the marketing of products which are considered not to be harmful for environment (Mohajan, 2012). In general, green marketing is a much broader concept that can be applied to consumer or industrial goods and even services. Green marketing is a process based on environmental benefits by selling products and services (Hashim et al., 2020). The success of Green brands becomes necessary to keep our earth alive and help the sustainability of humanity. Environmental issues also push consumers to be more proactive and open to green consumption. Especially for large companies from the main reasons for "being green", consumers' perceptions of green products, improving community relations and cost-effective management (Ulun, 2018). 
Organizations are interested in producing green products and services by organizing green marketing campaigns to accordingly change customer behavior. In fact, companies seeking green marketing face many challenges mainly from demand volatility, high cost and unfavorable consumer perception (Chen \& Chai, 2010).

On the other side, consumers have directed their concern about environmental issues through demand for environmentally friendly products, also the "Go Green" movement has expanded worldwide due to the intense awareness of living healthier (Norazah, 2013; Thøgersen et al., 2015). The green consumers demonstrate a great interest in product's characteristic as chemical content and its recyclability (Leonidou et al., 2010).

In addition, consumers who have positive past experience and some environmental brand knowledge with purchasing of green products have a high tendency to demonstrate strong intentions to purchase this green product due to its green attributes (Lin \& Chang, 2012; Norazah, 2013). Also, many consumers have limited knowledge about the reliability of green products and skeptical the quality of green products (Suki, 2016). So, consumers tend to search for more information and gain green brand knowledge related to the ingredients contain in green product before purchasing these products (Laroche et al., 2001). Prior scholars noted that extensive studies on green marketing had been conducted in Western countries, while minimal research on green purchasing behaviour and green branding had been pursued in developing countries (Suki, 2016). For that reason, the researcher is going to know in depth the Green branding knowledge \& trust in Egypt.

Previous results on consumer attitudes towards green brands are conflicting, for example, with some studies finding that consumers believe traditional products are of high quality compared to environmentally friendly products, but other studies show on the contrary (Vernekar \& Wadhwa, 2011), which considered one of the research problems to find out the impact of the attitude towards green brands from the Egyptian consumers' perspective on their purchase intention. 
Although green brand issues appear to be important issues in the world, unfortunately, previous studies have a gap of substantive research models to investigate the effects of the green brand knowledge and green brand trust on the green purchasing intention (GPI) via the mediating impact of attitude towards green brands in the Egyptian food \& beverage sector. These issues led the researcher to seek for more information and examine the impact of both green brand knowledge \& green brand trust on the purchasing intention via the attitude towards green brands. Moreover, these factors will be examined in detail from the Egyptian consumers' perspective in one of the most important sectors the food and beverage sector as it considered to be one of the oldest and vital sectors in the economy, this study would like to help marketers to develop a green marketing framework to understand consumers' mind $\&$ increase green purchase intentions via the two drivers: green brand knowledge and green brand trust.

\section{2- Research Problem}

Previous results on consumer attitudes towards green products are conflicting, for example, with some studies finding that consumers believe traditional products are of high quality compared to environmentally friendly products, but other studies show on the contrary (Vernekar \& Wadhwa, 2011), which considered one of the research problems to find out the impact of the attitude towards green brands from the Egyptian consumers' perspective on their purchase intention.

Although green brand issues appear to be important issues in the world, unfortunately, previous studies have a gap of substantive research models to investigate the effects of the green brand knowledge and green brand trust on the green purchasing intention (GPI) via the mediating impact of attitude towards green brands in the Egyptian food \& beverage sector. These issues led the researcher to seek for more information and examine the impact of both green brand knowledge \& green brand trust on the purchasing intention via the attitude towards green brands. Moreover, these factors will be examined in detail from the Egyptian consumers' perspective in one of the most important sectors the food and beverage sector as it considered to be one of the oldest and vital 
sectors in the economy, this study would like to help marketers to develop a green marketing framework to understand consumers' mind $\&$ increase green purchase intentions via the two drivers: green brand knowledge and green brand trust.

\section{3- Research Questions}

As in light of the researcher's effort and his knowledge, the researcher is testing the impact of these variables in Egyptian food \& beverage sector, but there are few types of research discussed those variables. Thus, this study is going to examine and answer questions on how green brand knowledge and green brand trust affect consumers' green purchasing intentions, especially from a consumer perspective.

RQ1: Can green brand knowledge of the green brands has significant positive impact on Egyptian consumers' purchasing intention via attitude towards green brands?

RQ2: Is green brand trust has significant positive impact on the Egyptian consumers' green purchasing intention through attitude towards green brands?

RQ3: Do positive/ negative attitudes towards green brands lead to increase or decrease Egyptian consumers' purchasing intention?

\section{4- Research objectives}

4-1 The impact of the green brand knowledge with its two dimensions (green brand awareness, green brand image) on the Egyptian consumers' green purchase intention directly, and indirectly via attitude towards green brands.

4-2 The impact of the green brand trust directly on the Egyptian consumers' green purchase intention and indirectly via attitude towards green brands.

4-3 The direct impact of attitude towards green brands on the Egyptian consumers' green purchase intention.

\section{5- Research Importance}

The research importance divided into two sections the academic \& the practical importance. Which will be discussed as follows: 


\section{5-1 Academic Importance}

Firstly, this research is academically important in many different ways. As, the term "Green" become synonymous with addressing environmental elements or issues (Yang \& Zhao, 2019). Green products have become more popular in the market (Huang et al., 2014). Thus, this research helps to understand the impact of the green brand knowledge $\&$ the green trust on the attitude towards these green brands \& its effect on the consumers purchasing intention.

Secondly, the importance of the research academically for the future researchers is to know in depth the importance, ability \& the impact of the green brand knowledge in changing the attitude towards green brands \& its effect on the purchasing intention based on Egyptian consumers' perspective in food \& beverage market sector. Also, looking at the importance of green brand trust, the current research tried to study the impact of green trust on consumers' attitudes in the context of eco-friendly green products and analyzed the subsequent effect on purchasing intention.

Thirdly, this research can have a significant impact on readers in relation to the consumer's role in the green marketing of consumer goods research and the protection of the earth from depletion resources. There're internal factors in green purchasing studies as in general, consumer environmental knowledge, attitude, and the intention were analyzed most often to capture the catalysts that influence green purchasing behavior (Ramayah et al., 2010; Almossaw, 2014; Wang et al., 2014; Newton et al., 2015; Moser, 2016; Paul et al., 2016).

\section{5-2 Practical Importance}

The importance of this research will help companies in their different fields of presenting and applying products or services to go green \& use eco-friendly ways in their manufacturing, marketing, even in the R\&D department. As it becomes one of the competitive advantages, to gain more market share and stay in the market. Besides, pushing companies to reduce the consumers' skepticism through their claims of making green \& eco-friendly products (greenwashing) while they are not, as it may cause profits but in a long run, they'll lose the customers trust \& 
they'll be erased from the market. Enhancing the understanding of the current state of green consumption, as well as the effects of green knowledge and attitude towards green brands, is critical to promote mass consumption or green purchasing intentions among those from low-income households particularly.

In addition, this study would like to help marketers to understand consumers' mind through developing green marketing framework to \& to increase green purchase intentions via the two drivers: green brand knowledge and green trust. Marketers play a vital role as they should communicate about the need \& benefits for green products to the consumers (Singhal \& Malik, 2018). The researcher also wants to help the companies \& marketers specifically to develop plans \& strategies to know how much consumers knowledge and trust in green brands in the Egyptian market (Green brand knowledge) particularly in the food and beverage sector. And if they've any intentions to purchase those kinds of products.

\section{6- Literature Review}

Green marketing is defined by the activities of companies that care about the environment or green problems by providing supported to create consumer and community satisfaction (Chen \& Chai, 2010). Since the consumers is more willing to purchase green products with sufficient trustworthy information, companies should provide reliable \& detailed information for their consumers in order to minimize the customers' skepticism (Chen \& Chang, 2012). This plays an important role in transforming the purchasing intention of users to actual purchase green products. The public is obviously concerned in environmental pollution, which is produced by industries and manufacturers of different types of products.

It is difficult for marketers trying to convince their customers to purchase their products without providing enough reliable information about it to their customers. The majority of consumers are not well aware of the benefits of green products that contribute to their purchases (Nagaraju \& Thejaswini, 2016). Consumers who have some environmental concerns are positively influenced by their purchasing 
decision of green products and brand awareness, Hence the role of marketers is providing information relating to the green products.

In the green marketing context, more \& more companies dedicate such great efforts to adopting green marketing strategies to satisfy customers' needs \& demands, also to gain competitive advantage (Jialing et al., 2017). Despite the launch of many environmental conservation campaigns, somehow green is a new concept for many citizens and their perception of environmentally friendly products is low (Rezai et al., 2013). To trigger \& maintain consumers' behavior \& attitude, the green marketing process should involve all marketing activities. (Chen and Chang, 2012). The "Green" term become synonymous with addressing environmental elements or issues (Chen, 2010). Environmental activists and researchers who are engaged in green products purchase believe that purchasing green eco- friendly products have a significant effect on improving the quality of environment (Abdul-Muhmin 2007). So, green products have become more popular in the market (Huang et al., 2014), and in turn, more consumers are willing to purchase environmentally friendly products (Huang et al., 2014). Green as a term refers to the actions that influence minimize on the environment, such as recycling or environmental purchase (Wolfe \& Shanklin, 2001). More attention has been paid to green products market (Kumar et al., 2017; Moser, 2016).

The formation of "the green consumers" or "the green market" segment is because of the increasingly aware of the consumers to the consequences of their consumption act (Curvelo et al., 2019). Green Customers are referred to the individuals who spend their money to purchase green products and have a high level of knowledge and environmental awareness (Suki, 2016). Green consumers are the consumers whom aware of and care about environmental issues (Soonthonsmai, 2007). These green consumers usually actively encourage the preservation of the planet, organize petitions and boycott manufacturers and retailers who have violated and caused harm to the environment (Chen and Chai, 2010).

There's a research highlighted the definition of the green product as a product that would not contaminate the land or consume natural resources and could be preserved or recycled (Chen and Chai, 2010). 
Green product also can be known as it contains environmentally content or packaging that reduce the impact on the environment (Chen and Chai, 2010). Minimal research has been conducted on understanding the efficacy and impact of green brand knowledge \& green brand trust on consumers' green purchase intention via attitude towards green brands. Some scholar claimed that it is necessary to explore further how the green brand factors impact attitude and green purchase behaviors (Chen, 2010; Rios et al., 2006).

\section{6-1 Green Brand Knowledge}

As, Consumer knowledge and trust is a prerequisite for creating a market for credible goods, such as "green" products. In general, knowledge reflects the characteristic that affects all stages of the decision-making process, which may form either positive or negative attitudes towards a particular behavior (Mei et al., 2012). Keller (1993) defines brand knowledge as "a brand node in memory to which a variety of associations are linked". Brand knowledge contains remarkable types known as brand awareness and brand image (Keller, 1993). Brand knowledge is a unique combination of brand awareness and brand image.

The buyers' ability to recall and recognize that the brand is green (environmentally- friendly) is known as green brand awareness (Tseng, 2013). The possibility that the brand name will come to mind and with whom it does so are linked to the brand name awareness (Keller, 1993). The brand image has symbolic meanings associated with the specific features of the brand in addition, it can be defined as the consumer's mental image of the brand in its mind associated with the display (Punyatoya, 2015). Chen (2010) defines the green brand's image as a whole set of brand impressions, concepts and concerns in customer memory that are linked to sustainability and environmentally friendly concerns. Suki (2016) mentioned in his research that green purchase behavior can be influenced negatively by the lack of reliable information. Consumers with a high level of environmental knowledge have a much better pro-environmental attitude and have a stronger intent to purchase green products for consumption (Suki, 2016). While other previous studies as Wolsink (2007), could not determine any links between environmental knowledge and green purchase intention. While 
some other studies suggest that green knowledge is not necessarily the direct prerequisite variable of the intention of green purchasing (Wang et al., 2019). Even there're some studies show that there is no significant relation between green knowledge and the green purchasing intention, other studies showed that environmental knowledge has a negative effect on pro-environmental attitude (Wang et al., 2019). Numerous studies have reported that environmental knowledge positively impacts consumers' intention and actual purchase of green products (Suki, 2016). Some previous studies suggest that green knowledge is often seen as a direct pre-change of green purchasing intentions (Wang et al., 2019). Accordingly, this posits that:

H1: there's a significant positive impact of green brand knowledge (GBK) on attitude toward green brands (AGB).

H2: there's a significant positive direct impact of green brand knowledge (GBK) on consumers' green purchase intention (GPI).

H3: there's a significant positive indirect impact of green brand knowledge (GBK) on consumers' green purchase intention (GPI) via attitude toward green brands (AGB).

\section{6-2 Green Brand Trust}

Trust is an expectation, which is held by one party as a word, promise or even a statement in which the other party can rely on, and trust is caused by three beliefs, which are charity, ability \& integrity (Chen and Chang, 2012). Also, trust plays an important role in consumer behavior, so the ability of brands to create a sense of trust affects the intention to purchase (Emre and Paul, 2016). Trust is defined as the brand's honesty in its promises and claims to be able to deliver on its promises. In fact, trust can enhance purchasing behavior and also reduce customer perception of risk (Yang and Zhao, 2019). The brand relationship variable as "brand trust," plays an important role in affecting buying behavior for long-term brand success (Esch et al., 2006). Consumer's green trust in the environmental claims for brands has an impact on purchasing decisions (Emre and Paul, 2016). Chen and Chang (2012) argue that in the environmental era the consumers' purchasing behavior influenced by their green trust. Customer purchasing intentions 
positively affected by customer trust as indicated by (Lu et al., 2010). Previous research shows that customer trust would positively influence customer purchase intentions (Chen \& Chang, 2012). Consumer behavior has many determinants, the main determinant for a long-term consumer behavior is consumer trust (Lee et al., 2011). Hence, consumers' trust affects consumer purchasing intentions (Harris \& Goode, 2010).

Therefore, this study proposes the following hypothesis:

H4: there is significant positive impact of green brand trust on consumers' attitude toward green brands (AGB).

H5: there's a significant positive direct impact of green brand trust (GBT) on consumers' green purchase intention (GPI).

H6: there's a significant positive indirect impact of green brand trust (GBT) on consumers' green purchase intention (GPI) via attitude toward green brands $(A G B)$.

\section{6-3 Attitude towards Green Brands}

Attitude can be defined as a personal subjective evaluation of a product or brand (Bodur et al., 2000). The attitude towards the green brand is attached to both consumers' full evaluation of the brand \& his preferences, which embodies his likes \& dislikes (Suki, 2016). The consumer's attitudes towards environmentally sustainable (green) products are essentially positive, as consumer environmental concern is on the rise (Cheah \& Phau, 2011). Attitudes are the most consistent explanatory factor in predicting consumers' willingness to green products purchasing (Chyong et al., 2006), which means that price is not the main factor in preventing consumers from buying green products if they are environmentally friendly. The attitude of the consumers is highly positive towards green branding (Singhal \& Malik, 2018). The attitude towards the brand is defined as the general evaluative judgment of the brand's consumers based on his trademark beliefs (Punyatoya, 2015). Also attitude defined as a positive or negative evaluation of an object, work, issue or person (Fishbein \& Ajzen, 1977).

In the context of a green product, the attitude can be defined as a form of admiration or hatred, pleasure or displeasure, comfort or discomfort as a form of positive or negative full evaluation of the individual towards 
green environmentally oriented product (Ginsberg \& Bloom, 2004). Former researchers noted that the consumers' environmental attitude reflect on their purchasing intentions (Suki, 2016), So Norazaha Suki (2016) made some research efforts which found that the consumers' who have a positive attitude toward a specific brand tend to have a strong purchasing intention towards this brand. Yadav and Pathak (2016) confirmed that attitude toward green products of the consumers significantly impacts his or her green purchase intention. There's a research that developed and tested a model of green behavior among Chinese consumers in which the researcher suggested that the trend of man-nature had a direct impact on attitudes toward green purchases, in which this in turn would affect the green purchasing intention (Ainsworth et al., 2016). There're many previous studies, as some green marketing studies also show that a positive attitude toward green products influences purchase intention (Huang et al., 2014).

Therefore, the following hypothesis is devised:

H7: Attitude towards green brands has a significant positive effect on green purchasing intention.

\section{6-4 Green Purchase Intention}

The purchase intention is mainly a situation that can make a person feel happy about things or attitudes or some ideas that are usually followed by someone's feelings and the tendency to look for objects. Rangkuti \& Sulistyawati (2014) stated that the emergence of the intention to buy a product was based on consumers' belief in the product that was accompanied by the ability to purchase the product. Suki (2016) stated that there is an intention among the consumers to purchase green products that causes less harmful impacts to the society and the environment. "Green purchase intentions" refers to Netemeyer et al. (2005) and Morrison (1979) to define it as "the likelihood that a consumer would buy a particular product resulting from his or her environmental needs". From the previous Literature study and the previous studies, the researcher presents the proposed model depending on the hypotheses is as shown: 


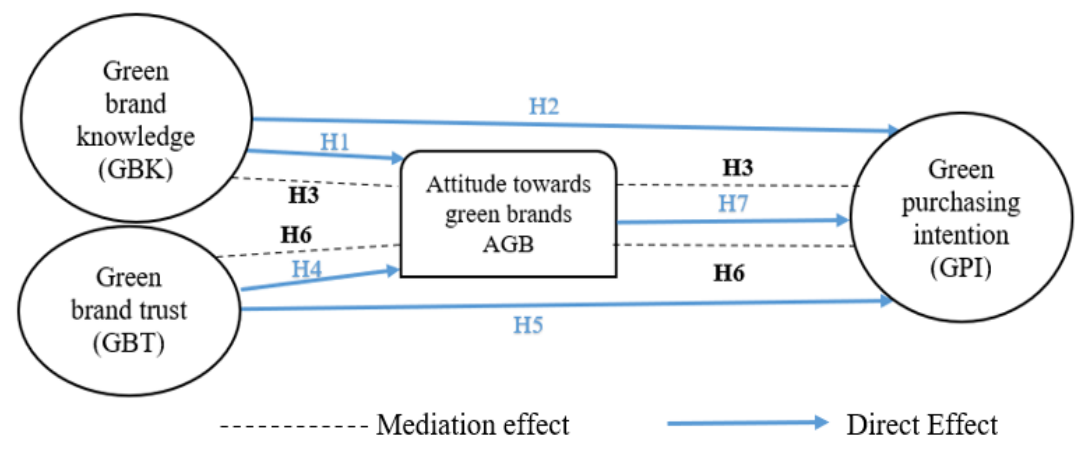

Fig 1: The relationship between the variables as in literature review

\section{7- Methodology}

The aim of this study is to test the impact of both independent variables (green brand knowledge \& green trust) on the green purchasing intention as a dependent variable via consumers' attitude towards the green brands (mediating variable). The researchers were not able to obtain the sampling frame therefore, they used the convenience technique which is considered one of the non-probability sampling technique. The population of the study consisted of only Egyptian consumers of products in the food \& beverage sector in most frequent malls \& supermarkets with especial focus on the food and beverage sectors products. According to the statistical tables used to determine the sample size, the appropriate sample size when the research community is more than 500,000 is (384) sample (Krejcie \& Morgan, 1970), and the sample has been increased by 16 individuals due to the avoidance of non-response or the absence of some survey lists for statistical analysis, to the final sample size is 400 individuals. Data have been collected in the quantitative phase via electronic questionnaires survey, which was developed and distributed among Egyptian customers to test the research hypotheses, which were developed from literature reviews, the results of the questionnaire provided data that were analyzed quantitatively by using SPSS to test the correlation \& regression between those variables and to achieve research objectives of the study. In addition to determine the impact of the green brand knowledge, green trust on the green purchasing intention in the Egyptian food \& beverage sector on the green purchasing intention. 
The study refers to former researches to develop questionnaire items to be suitable for the green products \& Egyptian market. The questionnaires were distributed to consumers according to the nonprobability convenience sampling technique. The measurement of the questionnaire items in this study is by means of "five-point Likert scale from 1 to 5 " rating from strongly disagree to strongly agree. In order to obtain reliable information from the respondents, established and validated scales were selected for data collection. The researcher sent and distributed electronic Google form questionnaires through online social media platforms to the customers from Cairo, Giza, Alexandria and Aswan cities. The questionnaires were written in both languages, Arabic and English. In order to make it easy for the consumers to answer the questions frankly \& easily without any interfering from the researcher. The questionnaires consist of 5 parts. The researcher developed scales for the green brand knowledge which have 12 items with its factors: green brand image (4 items) and green brand awareness ( 8 items) from Keller (1993), green trust from Chen (2010) with (5 items), attitude towards green brands from Patrick et al. (2005) which consists of: cognitive and emotional elements (4 items each), and finally the green purchasing intention from Pavlou (2003) and Chang \& Chen (2008) with (3 items).

\section{8- Results and Analysis}

\section{8-1 Descriptive Statistics}

The questionnaires were carried out with 400 Egyptian customers based on a convenience sampling technique as the researchers were not able to obtain the exact sampling frame of the study. The sample size of the research was (400) customers. According to the statistical tables used to determine the sample size, the appropriate sample size when the research community is more than 500,000 is (384) sample (Krejcie \& Morgan, 1970), and the sample has been increased by 16 individuals due to the avoidance of non-response or the absence of some survey lists for statistical analysis, to the final sample size is 400 individuals. The researcher distributed (150) electronic questionnaires in Cairo and Giza city social media platforms, also (150) electronic questionnaires in Alexandria city social media platforms, and (100) electronic 
questionnaire in Aswan city social media platforms. The research only took place in the four cities in Egypt (Cairo, Giza, Alexandria and Aswan), the country's capital and two of its major cities and the city that attract investors in upper of Egypt and named as the capital of the youth in the African continent as a representative of upper Egypt governorates. The researcher distributed more in Cairo, Giza, and Alexandria malls because the population density in those cities is more than Aswan city. In addition, the number of malls and hypermarkets and the density of frequent customers is more in those cities than Aswan city malls. In addition, this sector has been selected because these products are considered shopping goods, which require the customer to think well and deeply before making a purchasing decision especially after the spread of epidemics, viruses and preservatives in ready-made foods and beverages compared to that type of goods.

The researcher received 397 valid electronic questionnaires excluded 2 questionnaires due to the invalid answers \& excluded one questionnaire because the questionnaire was incomplete. From the Alexandria city social media platforms, the researcher accepted the valid 150 electronic questionnaires' answers each one constituted (37.5\%) of the total sample and it represent (37.7\%) of the total valid questionnaires. From Cairo and Giza cities social media platforms, the researcher received the 150 electronic questionnaires' answers, it constituted (37.5\%) of the total sample and after the exclusion of the two invalid electronic questionnaire the total number of valid questionnaires to be 148 valid electronic questionnaire which represent (37\%) of the total sample and also, they constituted (37.2\%) of the total valid questionnaires. From Aswan city the researcher distributed and received 100 questionnaires which represent (25\%) of the total sample, the researcher accepted 99 valid electronic questionnaire and excluded one questionnaire because the reason of incomplete. The valid electronic questionnaires represent $(24.75 \%)$ of the total sample and constituted (24.93\%) of the total valid questionnaires.

Customers' age in the sample ranged from twenty years old, which is the acceptable logical age to answer the questionnaire and named as consumers, to fifty years old and above. 177 customers aged 20 to less than 30 represent the greatest portion $(44.5 \%)$ of the sample. In 
addition, 51 customers aged above 50 represent the smallest portion (11.3\%) of the sample. Customers' current occupations varied from managers, professionals, academics, technicians, students, Housewives, unemployed and self-employed. The largest portion includes 149 academics, which represent (37.5\%) of the sample. the smallest portion was 17 unemployed and on pension employees, each represent (4.2\%) of the sample. Customers' income level ranged from less than 2000 , from 2000 to less than 4000, from 4000 to less than 6000 and finally above 6000 L.E. The largest portion of customers who earned above 6000 was 137 customers, which represents (34.5\%) of the sample. However, the smallest portion was 49 who earned less than 2000 represent (12.3\%) of the sample. Customers' education level ranged from intermediate to postgraduate degrees. The largest portion was 234 who got the bachelor's degree, and this portion represents (58.9\%) of the sample. And the smallest portion was 6 who hold intermediate degrees or less represent $(1.5 \%)$ of the sample.

\section{8-2 Reliability}

Reliability is defined as an evaluation and assessment of the degree of consistency between variable's multiple measurements (Hair et al., 2010).

Table 1: Reliability of variables

\begin{tabular}{|l|c|c|}
\hline \multicolumn{1}{|c|}{ Variables } & No. of items & $\begin{array}{c}\text { Cronbach's } \\
\text { alpha } \\
\text { coefficient }\end{array}$ \\
\hline 1. Green brand knowledge & 12 & 0.945 \\
\hline 2. Green Brand trust & 5 & 0.942 \\
\hline 3. Attitude towards green brands & 8 & 0.941 \\
\hline 4. Green purchasing intention & 3 & 0.919 \\
\hline 5. All Variables "Questionnaire" & 28 & 0.978 \\
\hline
\end{tabular}

In addition, the total scale reliability for all variables is $\alpha=0.97$. This means that each scale will produce consistent result if measurements are made repeatedly.

\section{8-3 Validity Test}

The validity can be assessed by the Average Variance Extracted (AVE) and Composite Reliability. 
Table 2: the AVE and CR

\begin{tabular}{|c|c|c|c|}
\hline & factor1 & factor2 & factor3 \\
\hline AVE & 0.461 & 0.415 & 0.408 \\
\hline CR & 0.938 & 0.860 & 0.825 \\
\hline
\end{tabular}

The acceptable value of CR is 0.6 or above and the AVE with values above 0.5 considered accepted, but we can accept 0.4 when the composite reliability (CR) is higher than 0.6 and the convergent validity of the construct is still adequate (Fornell \& Larcker, 1981).

Table 3: KMO \& Bartlett's test

KMO and Bartlett's Test

\begin{tabular}{|ll|r|}
\hline Kaiser-Meyer-Olkin Measure of Sampling Adequacy. & .972 \\
Bartlett's Test of & Approx. Chi-Square & 11606.029 \\
Sphericity & $\mathrm{df}$ & 378 \\
& Sig. & .000 \\
\hline
\end{tabular}

In addition, the validity test also can be assessed by Bartlett's Test of Sphericity \& Kaiser-Meyer-Olkin Measure of Sampling Adequacy as shown in table (3).

Tests the hypothesis that the correlation matrix is an identity matrix, which would indicate that the variables are unrelated and therefore unsuitable for structure detection. Small values (less than 0.05) of the significance level indicate that a factor analysis may be useful with the data. This result means that factor analysis is an appropriate technique.

$p-$ value $=0.000<0.05$

KMOs' test is a statistic way that indicates the proportion of variance in your variables that might be caused by underlying factors. High values (close to 1.0) generally indicate that a factor analysis may be useful with the data. If the value is less than 0.70 , the results of the factor analysis probably won't be very useful. 
Table 4: the correlation of the GBK with GPI Correlations

\begin{tabular}{|c|c|c|c|}
\hline & & GBK & GPI \\
\hline \multirow{3}{*}{ GBK } & $\begin{array}{l}\text { Pearson } \\
\text { Correlation }\end{array}$ & 1 & $.802^{* *}$ \\
\hline & Sig. (2-tailed) & & .000 \\
\hline & $\mathrm{N}$ & 397 & 397 \\
\hline
\end{tabular}

From the previous table (4), it shows the significant positive correlation between the independent variable green brand knowledge (GBK) and the dependent variable green purchasing intention (GPI). After computing the items of the green brand knowledge (GBK) variable as an independent variable and items of the green purchasing intention (GPI) variable as a dependent variable, the correlation between these two variables in general is 0.802 which is more than 0.5 , with p-value $<0.05$, which means there's a significant positive relationship between these two variables.

Table 5: the correlation of the GBK with AGB Correlations

\begin{tabular}{|c|l|c|c|}
\hline \multicolumn{2}{|c|}{} & GBK & AGB \\
\hline \multirow{3}{*}{ GBK } & Pearson Correlation & 1 & $.853^{* *}$ \\
\cline { 2 - 4 } & Sig. (2-tailed) & & .000 \\
\cline { 2 - 4 } & $\mathrm{N}$ & 397 & 397 \\
\hline \multirow{2}{*}{$* *$. Correlation is significant at the 0.01 level (2-tailed). } \\
\hline
\end{tabular}

From the previous table (5), it shows the significant positive correlation between the independent variable green brand knowledge (GBK) and the mediating variable attitude towards green brands (AGB) in which the " $r$ " value is positive and more than or equal 0.5 and the $p$ - value is less than 0.05. After computing the items of the green brand knowledge (GBK) variable as an independent variable and items of the attitude towards green brands (AGB) variable as a mediating variable, the correlation between these two variables in general is 0.853 which is more than 0.5 , with p-value $<0.05$, which means there's a significant positive relationship between these two variables. 
Table 6: the correlation of the GBT with GPI

Correlations

\begin{tabular}{|c|l|c|c|}
\hline \multicolumn{2}{|c|}{} & GBT & GPI \\
\hline \multirow{3}{*}{ GBT } & Pearson Correlation & 1 & $.823^{* *}$ \\
\cline { 2 - 4 } & Sig. (2-tailed) & & .000 \\
\cline { 2 - 4 } & $\mathrm{N}$ & 397 & 397 \\
\hline **. Correlation is significant at the 0.01 level (2-tailed). \\
\hline
\end{tabular}

From the previous table (6), it shows the significant positive correlation between the independent variable green brand trust (GBT) and the dependent variable green purchasing intention (GPI) in which the " $r$ " value is positive and more than 0.5 then it's significant positive correlation between these two variables. As shown in the table there's a significant positive relationship between the green brand trust and the green purchasing intention. Without the impact of the mediating variable (AGB). After computing the questions of the green brand trust (GBT) variable as an independent variable and questions of the green purchasing intention (GPI) variable as a dependent variable, the correlation between these two variables in general is 0.823 which is more than 0.5 , with $\mathrm{p}$ - value $<0.05$, which means there's a significant positive relationship between these two variables.

Table 7: the correlation of the GBT with AGB Correlations

\begin{tabular}{|l|l|c|c|}
\hline \multicolumn{2}{|c|}{ GBT } & AGB \\
\hline \multirow{3}{*}{ GBT } & Pearson Correlation & 1 & $.866^{* *}$ \\
\cline { 2 - 4 } & Sig. (2-tailed) & & .000 \\
\cline { 2 - 4 } & $\mathrm{N}$ & 397 & 397 \\
\hline \multicolumn{2}{|l|}{$*$. Correlation is significant at the 0.01 level (2-tailed). } \\
\hline
\end{tabular}

From the previous table (7), it shows the significant positive correlation between the questions of the independent variable green brand trust (GBT) and the mediating variable attitude towards green brands (AGB). After computing the items of the green brand trust (GBT) variable as an independent variable and items of the attitude towards green brands (AGB) variable as a mediating variable, the correlation between these two variables in general is 0.866 which is more than 0.5 , with p-value $<0.05$, which means there's a significant positive relationship between these two variables. 


\section{8-4 ANOVA Table}

As from the model summary and ANOVA those tell us overall, did the model with all the independent variables included, what was the $\mathrm{R}^{2}$. first, how much variance did it count for, and then was that variance that count for statistically significant that's the ANOVA and p-value.

Table 8: ANOVA of GBK, GBT and GPI

ANOVAa

\begin{tabular}{|l|l|c|c|c|c|c|}
\hline \multicolumn{2}{|c|}{ Model } & $\begin{array}{c}\text { Sum of } \\
\text { Squares }\end{array}$ & df & $\begin{array}{c}\text { Mean } \\
\text { Square }\end{array}$ & F & Sig. \\
\hline \multirow{3}{*}{1} & $\begin{array}{l}\text { Regressio } \\
\mathrm{n}\end{array}$ & 3869.302 & 2 & 1934.651 & 494.28 & $.000^{\mathrm{b}}$ \\
\cline { 2 - 6 } & Residual & 1542.128 & 394 & 3.914 & & \\
\cline { 2 - 6 } & Total & 5411.431 & 396 & & & \\
\hline \multicolumn{2}{|l|}{ a. Dependent Variable: GPI } \\
\hline \multicolumn{2}{|l|}{ b. Predictors: (Constant), GBT, GBK }
\end{tabular}

In this table (8), it shows that the model is significant in which its result is (.000) which indicates the p-value which is less than .05 (P-value< $0.05)$ so there's a model without the impact of the mediating variable attitude towards green brands (AGB). In which this model indicates that there're significant relations between both independent variables green brand knowledge (GBK) and green brand trust (GBT) and the dependent variable (GPI).

Table 9: Model summary of GBK, GBT and GPI

Model Summaryb

\begin{tabular}{|c|c|c|c|c|c|}
\hline Model & $\mathbf{R}$ & $\begin{array}{c}\mathbf{R} \\
\text { Square }\end{array}$ & $\begin{array}{c}\text { Adjusted R } \\
\text { Square }\end{array}$ & $\begin{array}{c}\text { Std. Error of } \\
\text { the } \\
\text { Estimate }\end{array}$ & $\begin{array}{c}\text { Durbin- } \\
\text { Watson }\end{array}$ \\
\hline 1 & $.846^{\mathrm{a}}$ & .715 & .714 & 1.97839 & 1.813 \\
\hline \multicolumn{5}{|l}{ a. Predictors: (Constant), GBT, GBK } \\
\multicolumn{5}{|l}{ b. Dependent Variable: GPI }
\end{tabular}

The model summary in table (9) indicates that there's a model between the two independent variables (GBK) and (GBT) and the dependent variable (GPI). In which, the adjusted $\mathrm{R}^{2}=.714$. That means that the independent variables GBK and GBT can account for a significant amount of variance in green purchasing intention without the effect of the mediating variable attitude towards green brands $(A G B)=71.4 \%$. In 
other words, the overall regression model is significant, $\mathrm{F}(2,394)=$ 494.2, $\mathrm{p}<.005, R^{2}=0.714$.

Table 10: ANOVA of GBK, GBT, AGB and GPI

ANOVAa

\begin{tabular}{|c|l|c|c|c|c|c|}
\hline \multicolumn{2}{|c|}{ Model } & $\begin{array}{c}\text { Sum of } \\
\text { Squares }\end{array}$ & df & $\begin{array}{c}\text { Mean } \\
\text { Square }\end{array}$ & F & Sig. \\
\hline \multirow{2}{*}{1} & Regression & 3994.795 & 3 & 1331.598 & 369.409 & $.000^{\text {b }}$ \\
\cline { 2 - 7 } & Residual & 1416.635 & 393 & 3.605 & & \\
\cline { 2 - 7 } & Total & 5411.431 & 396 & & & \\
\hline \multicolumn{2}{|l|}{ a. Dependent Variable: GPI } \\
\multicolumn{2}{|l}{ b. Predictors: (Constant), AGB, GBK, GBT } \\
\hline
\end{tabular}

In this table (10), it shows that the model is significant in which its result is (.000) which indicates the p-value which is less than .05 (P-value $<$ $.05)$, So there's a model with the impact of the mediating variable attitude towards green brands (AGB). In which this model indicates that there're significant relations and a research model between both independent variables green brand knowledge (GBK) and green brand trust (GBT), the mediating variable attitude toward green brands, and the dependent variable (GPI).

Table 11: Model summary of GBK, GBT, AGB and GPI

\section{Model Summaryb}

\begin{tabular}{|c|c|c|c|c|c|}
\hline Model & $\mathbf{R}$ & $\begin{array}{c}\mathbf{R} \\
\text { Square }\end{array}$ & $\begin{array}{c}\text { Adjusted R } \\
\text { Square }\end{array}$ & $\begin{array}{c}\text { Std. Error of } \\
\text { the Estimate }\end{array}$ & $\begin{array}{c}\text { Durbin- } \\
\text { Watson }\end{array}$ \\
\hline 1 & $.859^{a}$ & .738 & .736 & 1.89860 & 1.782 \\
\hline \multicolumn{5}{|l}{ a. Predictors: (Constant), AGB, GBK, GBT } \\
b. Dependent Variable: GPI
\end{tabular}

In the following table (11), after adding the impact of the mediating variable (AGB), the model summary indicates that there's a model between the two independent variables (GBK) and (GBT), the mediator (AGB), and the dependent variable (GPI). In which, the adjusted $\mathrm{R}^{2}=.736$. That means that the independent variables GBK and GBT can account for a significant amount of variance in mediating variable AGB and strength the relation between these two independent variables and the dependent variable GPI. In other words, the overall regression model is significant, $\mathrm{F}(3,393)=369.4, \mathrm{p}<.005, R^{2}=0.736$.

The model can be written as: 


$$
\mathrm{GPI}=0.211+0.112(\mathrm{GBK})+0.329(\mathrm{GBT})
$$

The model summary taken as a set which means that the (predictors) independent variables GBK and GBT in the model explained $73.6 \%$ of the variance for the dependent variable (GPI)from SPSS analysis indicates that there's a model between the two independent variables (GBK) and (GBT) and the dependent variable (GPI). In which, the adjusted $\mathrm{R}^{2}=.714$. That means that the independent variables GBK and GBT can account for a significant amount of variance in green purchasing $=71.4 \%$. In other words, the overall regression model is significant, $\mathrm{F}(2,394)=494.2, \mathrm{p}<$ $.005, R^{2}=0.714$.

\section{8-5 PROCESS v. 3.5.2 by Andrew F. Hayes Test Results}

In the first part of the research model, the independent variable is the Green brand knowledge (GBK) which can be indicated by $\mathrm{X}$, the mediating variable is the attitude towards green brands (AGB) indicated by $\mathrm{M}$, and the dependent variable is the green purchasing intention (GPI) indicated by Y.

The second part of the research model, the independent variable is the Green brand trust (GBT) which can be indicated by X, the mediating variable is the attitude towards green brands (AGB) indicated by $\mathrm{M}$, and the dependent variable is the green purchasing intention (GPI) indicated by Y.

The researcher used this program in SPSS known by PROCESS procedure written by Andrew F. Hayes. According to the model templates for PROCESS for SPSS 2013-2016 by Andrew F. Hayes and The Guilford Press, there are many models in this template the researcher used model no. (4) as shown in fig. (10) which indicates one independent variable in the first part of the research model will be green brand knowledge (GBK) while in the second part of the research model the IV will be green brand trust (GBT), the mediator in both parts of the research model will be the attitude towards green brands (AGB) and the dependent variable is the green purchasing intention (GPI).

In the first part of the research model and according model (4) as shown in fig. 
(10), the researcher referred the green brand knowledge (GBK) as point $(\mathrm{X})$, while the attitude towards green brands (AGB) as point (M) and finally the green purchasing intention (GPI) as point (Y). In the second part of the research model and according model (4) as shown in fig. (10), the researcher referred the green brand trust (GBT) as point (X), while the attitude towards green brands (AGB) as point (M) and finally the green purchasing intention (GPI) as point (Y).

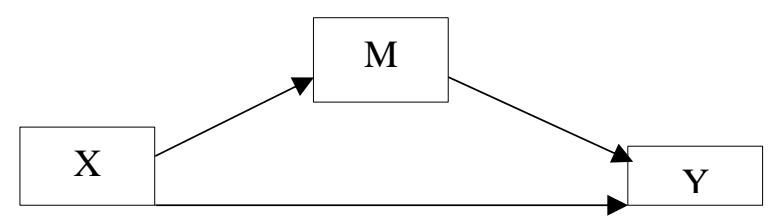

Fig 2: Model 4 in model templates for PROCESS for SPSS 2013-2016 by Andrew F. Hayes and The Guilford Press

The results from the SPSS were as follows:

Model: 4

Y: GPI

$\mathrm{X}$ : GBK

M: AGB

Sample

Size: 397

* DIRECT AND INDIRECT EFFECTS OF X ON Y

Direct effect of $\mathrm{X}$ on $\mathrm{Y}$

Effect se $t \quad p \quad$ LLCI ULCI

$\begin{array}{llllll}.1112 & .0156 & 7.1182 & .0000 & .0805 & .1419\end{array}$

Indirect effect(s) of $\mathrm{X}$ on $\mathrm{Y}$ :

Effect BootSE BootLLCI BootULCI

$\begin{array}{lllll}\text { AGB } & .1325 & .0167 & .0994 & .1646\end{array}$

$* * * * * * * * * * * * * * * * * * * * * * *$ ANALYSIS NOTES AND ERRORS

Level of confidence for all confidence intervals in output:

95.0000

Number of bootstrap samples for percentile bootstrap confidence intervals:

5000 
From these results, the direct effect between the green brand knowledge (GBK) as an independent variable referred by symbol (X) and the green purchasing intention (GPI) as a dependent variable referred by symbol $(\mathrm{Y})=.1112$ and its $\mathrm{p}$ - value $<0.05$ which means that its statistically significant. Also, the lower limit confidence interval (LLCI) is 0.0805 and the upper limit confidence interval (ULCI) is 0.1419 , the output based on the $p$-value $(p<0.05)$, and both LLCI and ULCI values $\neq 0$ indicates significant effects between the green brand knowledge (GBK) as an independent variable referred by symbol $(\mathrm{X})$ and the green purchasing intention (GPI) as a dependent variable. From the same results, the indirect effect between the green brand knowledge (GBK) as an independent variable referred by symbol $(\mathrm{X})$ and the green purchasing intention (GPI) as a dependent variable referred by symbol (Y) via the mediating effect of the attitude towards green brands (AGB) referred by symbol $(M)=.1325$, and its $p$ - value $<0.05$ which means that its statistically significant. These results means that There's a partial mediating effect between the green brand knowledge (GBK) as an independent variable and the green purchasing intention (GPI) as a dependent variable via the mediating effect of the attitude towards green brands (AGB).

In addition, the indirect effect between the green brand knowledge (GBK) as an independent variable and the green purchasing intention (GPI) as a dependent variable via the mediating effect of the attitude towards green brands (AGB) $=.132$ is more than the direct effect between the green brand knowledge (GBK) as an independent variable and the green purchasing intention (GPI) as a dependent variable which $=.111$, and it's the same results indicated by the Sobel test.

The researcher analyzed also the both dimensions of the green brand knowledge as an independent variable (green brand awareness and green brand image) and their impact directly on the green purchasing intention as a dependent variable and indirectly via the attitude towards green brands. The results of assuming that the green brand awareness only as an independent variable and impacts directly on the green purchasing intention $(=.894)$, while the indirect impact via the attitude towards green brands as a mediator (=.4773), which means that the direct impact in more impact than the indirect impact. In assuming that 
the green brand image only as an independent variable and impacts directly on the green purchasing intention $(=.1770)$, while the indirect impact via the attitude towards green brands as a mediator $(=.1786)$, which means that the direct impact in less impact than the indirect impact.

The results from the SPSS were as follows:

****************** DIRECT AND INDIRECT EFFECTS OF X ON Y

Direct effect of $\mathrm{X}$ on $\mathrm{Y}$

\begin{tabular}{ccclll} 
Effect & $\mathrm{se}$ & $\mathrm{t}$ & $\mathrm{p}$ & LLCI & \multicolumn{2}{c}{ ULCI } \\
.2834 & .0341 & 8.3195 & .0000 & .2165 & .3504
\end{tabular}

Indirect effect(s) of $\mathrm{X}$ on $\mathrm{Y}$ :

Effect BootSE BootLLCI BootULCI

$\begin{array}{lllll}\text { AGB } & .2490 & .0395 & .1752 & .3313\end{array}$

ANALYSIS NOTES AND ERRORS

Level of confidence for all confidence intervals in output:

95.0000

Number of bootstrap samples for percentile bootstrap confidence intervals: 5000

From these results, the direct effect between the green brand trust (GBT) as an independent variable referred by symbol (X) and the green purchasing intention (GPI) as a dependent variable referred by symbol $(Y)=.2834$ and its $p$ - value $<0.05$ which means that its statistically significant. Also, the lower limit confidence interval (LLCI) is .2165 and the upper limit confidence interval (ULCI) is .3504, the output based on the $\mathrm{p}$-value $(\mathrm{p}<0.05)$, and both LLCI and ULCI values $\neq 0$ indicates significant effects between the green brand trust (GBT) as an independent variable referred by symbol $(\mathrm{X})$ and the green purchasing intention (GPI) as a dependent variable. From these same results, the indirect effect between the green brand trust (GBT) as an independent variable referred by symbol (X) and the green purchasing intention (GPI) as a dependent variable referred by symbol $(\mathrm{Y})$ via the mediating effect of the attitude towards green brands (AGB) referred by symbol (M)= .2490. These results means that There's a partial mediating effect between the green brand trust (GBT) as an independent variable and the 
green purchasing intention (GPI) as a dependent variable via the mediating effect of the attitude towards green brands (AGB).

In addition, the indirect effect between the green brand trust (GBT) as an independent variable and the green purchasing intention (GPI) as a dependent variable via the mediating effect of the attitude towards green brands (AGB) $=.249$ is less than the direct effect between the green brand knowledge (GBK) as an independent variable and the green purchasing intention (GPI) as a dependent variable which $=.283$.

\section{9- Discussion}

This study showed the importance of studying and understanding the green brand knowledge and green brand trust that contribute to the strengthening of green purchasing intention in the food and beverage sector via the consumers' attitude towards green brands. Particularly, this study is considered one of the few researches that combined green brand knowledge, green brand trust, consumers' attitude towards green brands and green purchasing intention as a united chain within the Egyptian food and beverage sector. There're previous studies that studied the first part of the research model which illustrates the relationship between the green brand knowledge and green purchasing intention directly and indirectly via the attitude towards green brands (Kumar et al., 2017). As the results of the current research model for the impact of the green brand knowledge on green purchasing intention via the attitude towards green brands proved that the indirect impact via the attitude towards green brands impact more than the direct impact between the green brand knowledge and green purchasing intention. These findings were supported by the previous studies as follows: Firstly, Suki (2016) stated that the development of organic attitudes positively affected by the knowledge of organic food. A previous study also showed that consumers with a high level of environmental knowledge have a much better pro-environmental attitude and have a stronger intent to purchase green products for consumption (Suki, 2016). Also, Suki (2016) mentioned in his research that green purchase behavior can be influenced negatively by the lack of reliable information. In addition, from the findings that were supported by the previous studies, A research by (Park and Sohn, 2018) mentioned that in 
Fishbein's (1963) attitude development theory, it is posited that the attitude toward a product is developed based on the attributes of the product and the individual's assessment of its attributes, which also means that knowledge as attribute information is a factor in attitude development. Most green marketing studies that focus on the perception have shown that the environmental attitudes of the consumer clearly influence by environmental knowledge (Huang et al., 2014). A study by Suki, (2016) reported that green brand knowledge significantly affected consumers' attitude toward green brands. Besides, Aaker and Joachimsthaler (2002) showed that both of positive image of the brand \& highly brand awareness enhances consumers' brand attitudes. Also, A study by (Amoako et al., 2020) presented a model that argues that the youth's purchasing behavior is influenced by green knowledge and attitude, in which green attitude influences buying behavior and that green knowledge influences purchasing behavior. Rand Corporation (2004) also demonstrated that there is less opportunity for the average consumer to form an attitude on an environmentally friendly green product than around a generic product unless the customer tries to increase his green knowledge about the product, which support the currently research findings as most of the customers agreed on that point of view.

lastly, previous studies have reported that environmental knowledge positively impacts consumers' intention and actual purchase of green products (Suki, 2016). While some other studies that don't agree with the findings in this research, suggest that green knowledge is not necessarily the direct prerequisite variable of the intention of green purchasing (Wang et al., 2019). As, in this research the attitude towards green brands as a mediating variable between the green brand knowledge and the green purchasing intention has a positive effect more than the direct effect between green brand knowledge and the green purchasing intention.

On the other hand, there're some previous studies that didn't support the current research findings or disagree with it. From these previous studies as Wolsink (2007) could not determine any links between environmental knowledge and green purchase intention. Other studies showed that environmental knowledge has a negative effect on pro- 
environmental attitude (Wang et al., 2019). While other studies partially support that there's a relation between the green brand knowledge and attitude towards green brands as, studies affirmed that environmental knowledge moderated the effect of consumer ecological attitude toward green behavior (Suki, 2016). Some previous studies suggest that green knowledge is often seen as a direct pre-change of green purchasing intentions.

The findings in the other part of the research model showed the direct impact of green brand trust on green purchasing intention more than the indirect impact via consumers' attitude towards green brands. From other previous studies that support the research findings. Firstly, that regarding the impact of the consumer trust on the purchase intention, Punyatoya (2015) study indicates that brand trust is positively related to eco-friendly brand attitude. In addition, a study by (Chen \& Chang, 2012) develops a research framework of green purchase intentions to further discuss its relationships with green trust and found that the empirical results show that there's a positive relationship between green trust and green purchase intentions. in addition, a positive \& significant relationship between these two variables in a study carried out in Taiwan as Teng and Wang (2015) found out. Also, a previous research test including green brand trust in the structural model of the theory of planned behavior, which its results also suggested that trust is positively affect consumer purchase intention (Curvelo et al., 2019). In a research by (Aydin et al., 2014), they stated that trust in high market share brands is also high, and that individuals may show a tendency to trust the brands they see most often, and that they notice being purchased more often. From the findings that also support the indirect impact via the attitude towards green brands from current research findings, in 2011, Joji studied two different brands and stressed in his research that positive brand trust leads to a positive brand attitude toward that brand, also according to Joji (2011), trust leads to confidence in the brand and results in shaping a strong positive belief towards the brand.

From the previous research findings that support the current findings between the relation between the attitude towards green brands and green purchasing intention, Former researchers noted that the consumers' environmental attitudes reflect on their purchasing 
intentions (Suki, 2016), So Suki (2016) made some research efforts which found that the consumers' who have a positive attitude toward a specific brand tend to have a strong purchasing intention towards this brand. Also, from the previous studies findings that support the research findings, a research by (Suki, 2016) found that the finding from their quantitative research proves that consumers' attitude toward green brands have a significant positive relationship with green product purchase intention. Besides some green marketing studies also supporting the current findings show that a positive attitude toward green brands influences purchase intention (Huang et al., 2014).

\section{0- Conclusion and Contributions}

In today's market place, building a green brand knowledge and trust is not an optional choice but it is a must to build green brand equity to gain a sustainable competitive advantage. The results confirmed the importance and impact of green brand knowledge and green brand trust in changing the consumers' purchasing intention. Also, in this study green brand trust was confirmed to have the most direct impact on green purchasing intention in the Egyptian food and beverage sector. Building green brand trust requires the companies to provide reliable \& detailed information for their consumers in order to avoid the suspicious customers. As, the customers are more willing to purchase green products with sufficient trustworthy information. Also, the availability of reliable product's information can help to ease customer skepticism and suspicion and to raise customer green trust. As, false claims negatively affect green trust, purchase intention and word of mouth, in turn it creates doubts in the mind of the consumers (Ulun, 2018).

This study provides a significant advancement to the current literature of green branding, particularly in the green brand knowledge and green trust in the Egyptian food and beverage sector. This study also helps to understand the impact of the green brand knowledge \& the green trust on the consumers' purchasing intention. As green products have become more popular in the market (Raska \& Shaw, 2012). Some term as "Green" has become synonymous with addressing environmental elements or issues (Chen, 2010). This study focused on the ability and the great impact on how the green brand knowledge with its factors as brand 
awareness and brand image of the green brands could change the green purchasing intention. This research provides information about many concepts that hadn't been studied in the Egyptian as green brand knowledge, green trust, and green purchasing intention.

Since, selling and purchasing operations of the eco-friendly green products in Egypt is raising with the spread of COVID-19 virus. this study provides information about the relation between these variables in Egyptian food and beverage sector. As, the researcher reviewed the literature, few types of research discussed that variables \& the researcher couldn't find exactly a research discuss these variables as it is. Many researchers have analyzed consumer-friendly behavior in the European-American (Do Paco et al., 2009; Do Paco \& Raposo, 2010; Kronrod et al., 2012; Leonidou et al., 2010; Luchs et al., 2010; Rios et al., 2006) and Australian contexts (Cheah \& Phau, 2011; Phau \& Ong, 2007), and a few have researched the Asian context (Chen, 2010; Lee, 2011) but may none or few in the African context.

In addition, this research highlighted the importance of building and managing brand knowledge and green brand trust towards green brands, as an intangible asset in the food and beverage industry due to spread of epidemics and viruses and the increasing of the awareness towards healthy and Eco-friendly green products and finally the environmental sustainability, particularly in the Egyptian customers' mindset in the food and beverage sector. In conclusion, based on the results of the research, an objective research model was formed to be used by future researchers. Therefore, the distinctive contribution of this research arises from the provision of an objective research model that links and defines the impact of the green brand knowledge and green trust on the green purchasing intention with the mediating effect of the attitude towards green brands. Thus, this study helps to understand "Can green brand knowledge of the green brands impact directly the Egyptian consumers' purchasing intention?" and, "Is there a green brand trust among the Egyptian consumers'? And if there is, does green brand trust directly impact the Egyptian consumers' green purchasing intention?".

in result of the COVID-19 pandemic and the lockdown and social distancing mandates have developed some of the consumer habits of 
buying as well as shopping. These new habits which will also emerge by technology advances and purchasing Eco-friendly healthy food and beverage products, and changing demographics. So, this study urges purchasing green products has become a new and contemporary trend, which encourage companies to develop its products to be Eco-friendly and healthy product.

This research is academically important in many different ways. As, the term "Green" become synonymous with addressing environmental elements or issues (Yang \& Zhao, 2019). Green products have become more popular in the market (Huang et al., 2014). In some studies, we can find that consumers are willing to pay much more for green products, while in other studies, it is not the extra price should be low or even it is not the case (Vernekar et al., 2011). Thus, this research helps to understand the impact of the green brand knowledge \& the green trust on the consumers' purchasing intention. In addition, the importance of the research academically for the future researchers is to know in depth the importance, ability \& the impact of the green brand knowledge and green brand trust in changing the purchasing intention based on the points of views of the Egyptian food \& beverage consumers.

Practically, the importance of this research from the companies' view is trying to encourage and help the companies in their different fields of presenting and applying products or services to go green \& use ecofriendly ways in their manufacturing, marketing, even in the R\&D department. As it becomes one of the competitive advantages, to gain more market share and stay in the market. Besides, pushing companies to reduce the consumers' skepticism through their claims of making green \& eco-friendly products (greenwashing) while they are not, as it may cause profits but in a long run, they'll lose the customers trust \& they'll be erased from the market. Firstly, this study highlighted the importance of building and managing brand knowledge and green brand trust towards green products, as an intangible asset in the food and beverage industry due to spread of epidemics and viruses and the increasing of the awareness towards healthy and Eco-friendly green products and finally the environmental sustainability, particularly in the Egyptian customers' mindset in the food and beverage sector. Secondly, thirdly the importance of this research practically from the companies' 
view, is the researcher tried to highlight the increasing of the awareness of the customers towards green products and their attitude towards green products. As, Kim and Chung (2011) stressed that when consumers have a positive mindset for green purchases, they have a higher intention to use green products. And so, these companies should produce green and eco- friendly products in food and beverage sector. Also, the inputting of healthy and environmentally friendly materials in the manufacturing, packaging and recycling processes, as well as the product itself, should be healthy and natural and free of harmful ingredients that may harm the health of its users or the entire environment. For that reason, it is critical to identify green products that are available in the marketplace, to make it easier to investigate the consumer's attitude towards these green products. the researcher recommends companies to use various means of communication to market their brands and advertise them as green products to attract more consumers to buy it. One of the communication methods with the consumers is the green brand, as it provides reliable information about the products' unique attributes \& benefits, which particularly minimize the harmful impact on the environment \& represent green product attributes.

Also, the researcher recommends companies should use advertising claims like "eco-friendly", and "earth-friendly" and making consumers to "go green" and "save the planet". Companies need to disclose more sufficient trustworthy information about the environmental performance of their green products as its the role of marketers in order to gain consumers' trust to purchase these products. In addition, companies should apply green marketing strategies to strengthen the green brand trust of their products considering environmental concerns to raise their competitive advantage and effect the consumers' purchasing intention.

\section{1- Limitations and Direction for Future Researches}

the researcher focused on the green brand knowledge and green trust but did not take into consideration the impact of other the green brand equity factors. However, the concept can be taken into consideration in depth in future research to test its impact on the green purchasing 
behavior. Data collection only took place in the four cities in Egypt (Cairo, Giza, Alexandria and Aswan), the country's capital and two of its major cities and the city that attract investors in upper of Egypt and named as the capital of the youth in the African continent. Like many other developing countries, Egypt shows important inter regional differences such as education, income, etc. However, little is known about green products among customers in other cities. Future research can conduct the same study in other cities in Egypt. Because of the spread of COVID19 known as Coronavirus, there was suspension of the transportation from city to another which prevent the researcher to distribute the handed questionnaire to the targeted customers in Alexandria, Cairo and Giza cities. In addition, there was a noticeable change in customer visiting frequency ratios on malls in the targeted cities.

since this research was conducted in the Egyptian food and beverage sector, the replication for this study can be done within other sectors and industries (e.g., The mineral industry sector, for example, companies specialized in the production and manufacture of gasses and valves used in water and sanitation systems, textile industries, chemical industries, medical and health products as cosmetics or babies diapers, automotive and electrical appliances sector, construction materials sector etc....) because the factors that contribute in building the green brand knowledge and green brand trust may vary from one sector or industry to another. the researcher used in data collecting the electronic questionnaire as a quantitative data collection method, the future researchers should use handed questionnaire in order to be in touch with the targeted samples for any misunderstanding any question. In addition, the future researchers can mix with the quantitative data collection method the qualitative data collection method tools as interviews to know and explore more about their ideas and test their green brand knowledge and green trust and how it might change their attitude towards these brands and chance their green purchasing intention. In addition, cross-cultural research may reveal other links and relations regarding the impact of green brand knowledge and its factors and green trust and the effect of the attitude towards these green brands in the green purchasing intention, which may be similar or contradicting to this study. 
Future research can also test the impact of green washing and the false misleading claims of some companies in the attitude towards green brands and how it will affect the purchasing intention of the green products. Also, how the de-marketing concept to unhealthy and not Ecofriendly products may change the attitude towards green brands and impact the purchasing behavior for these types of green products. Lastly, this study focused more on the perception of customers. Future research can conduct this study through managerial and companies' perspectives. Future research can also do a comparative study with both perspectives (the managerial and the customer perspective). or even a comparative study between same food and beverage sector companies in how they market for their green products and build customers' green brand trust, knowledge and loyalty. Hence, by examining and comparing, green companies in food and beverage sector will be able to fill the gap (if it exists) between both perspectives and gain more expertise in the field of green products marketing.

\section{References}

Abdul-Muhmin, A. (2007). Exploring consumers' willingness to be environmentally friendly. International Journal of Consumer Studies. 31. 237 - 247. 10.1111/j.1470-6431.2006.00528. x.

Ainsworth, A.; Aditya, M.; Mojisola. F. T. (2016). GREEN consumption values and Indian consumers' response to marketing communications, Journal of Consumer Marketing, 7(33), 562573.

Ajzen, I., \& Fishbein, M. (1977). Attitude-behavior relations: A theoretical analysis and review of empirical research. Psychological Bulletin, 84(5), 888-918. https://doi.org/10.1037/00332909.84.5.888

Aydin, G.; Akdeniz AR.; Aybeniz, T.; Çağatan; Üniversitesi; Balıkesir; İibf; Bandırma; Bölümü; İşletme; Myo; Bandırma; Programı; Sosyal; Üniversitesi; Uludağ; İibf; İșletme \& Bölümü (2014). The Role of brand trust on parents' purchase intention of baby-care products Marka Güveninin Ebeveynlerin Bebek Bakim Ürünleri 
Satin Alma Niyetleri Üzerindeki Rolü. Doğuş Üniversitesi Dergisi. 15. 165-180. 10.31671/dogus.2018.84.

Nagaraju, B.; Thejaswini, H.D. (2016). A study on consumer attitude towards eco-friendly FMCG products with reference to Hubli city in Karnataka J. Bus. Manag., 18, 58-63.

Bodur, H.O.; Brinberg, D., \& Coupey, E. (2000). Belief, affect, and attitude: alternative models of the determinants of attitude. Journal of Consumer Psychology, 9(1), 17-28.

Cheah, I. and Phau, I. (2011). Attitude towards environment friendly products: the influence of ecoliteracy, interpersonal influence and value orientation, Marketing Intelligence \& Planning, 5(29), 452-472.

Chen, T. B. \& Chai, L.T. (2010). Attitude towards the Environment and Green Products: Consumers' Perspective, Management Science and Engineering, 2(4), 27-39.

Chen, Y. and Chang, C. (2012). Enhance green purchase intentions: The roles of green perceived value, green perceived risk, and green trust, Management Decision, 3(50), 502-520.

Chen, Y.-S. (2010). The drivers of green brand equity: green brand image, green satisfaction, and green trust, Journal of Business Ethics, (93) 2, 307-319.

Chih-Ching, T. and Yu-Mei, W. (2015). Decisional factors driving organic food consumption, British Food Journal, (117) 31066 - 1081.

Chyong, H.T.; Phang, G.; Hasan, H. and Buncha, M.R. (2006). Going green: A study of consumers' willingness to pay for green products in Kota Kinabalu, International Journal of Business and Society, 7(2), 40-54.

Curvelo, I. \& Watanabe, E., \& Alfinito, S. (2019). Purchase intention of organic food under the influence of attributes, consumer trust and perceived value. 10.1108/REGE-01-2018-0010.

Do Paco, A.M. and Raposo, M.L. (2010). Green consumer market segmentation: empirical findings from Portugal, International Journal of Consumer Studies, 4(34), 429-436. 
Do Paco, A.M.; Raposo, M.L. and Filho, W. (2009). Identifying the green consumers: a segmentation study, Journal of Targeting, Measurement and Analysis for Marketing, 1(17), 17-25.

Emre U., \& Paul G. B. (2016). How green are you, really? Consumers' skepticism towards brands with green claims, Journal of Emerald insight 1(7), 72-76.

Esch, F.R.; Langner, T.; Schmitt, B.H. and Geus, P. (2006). Are brands forever? How brand knowledge and relationships affect current and future purchases, Journal of Product and Brand Management, 2(15), 98-105.

Fornell, C., \& Larcker, D. (1981). Evaluating Structural Equation Models with Unobservable Variables and Measurement Error. Journal of Marketing Research, 18(1), 39-50. doi:10.2307/3151312

Ginsberg, J.M. and Bloom, P.N. (2004). Choosing the right green marketing strategy, MIT Sloan Management Review, 1(46), 7984.

Harris, L.C. and Goode, M. M. H. (2010). Online servicescapes, trust, and purchase intentions. Journal of Services Marketing, 2-3(24).230243. doi:10.1108/08876041011040631

Hashim, M., \& Abrar, M., \& Mohsin, M., \& Baig, S. (2020). Effects of Green Marketing on Green Purchase Intentions.

Huang, Y.C.; Yang, M. and Wang, Y.C. (2014). Effects of green brand on green purchase intention, Marketing Intelligence and Planning, 3(32), 250-268.

Joji, A.N. (2011). Consumer evaluations of product line brand extension, IUP Journal of Brand Management. 1(8), 22-35.

Keller, K.L. (1993). Conceptualizing, measuring, and managing customerbased brand equity, Journal of Marketing, 1(57), 1-22.

Kim, H., \& Chung, J. (2011). Consumer purchase intention for organic personal care products. Journal of Consumer Marketing. (28). 4047. 10.1108/07363761111101930. 
Krejcie, R. V., \& Morgan, D. W. (1970). Determining sample size for research activities. Educational and Psychological Measurement, 30(3), 607-610.

Kronrod, A.; Grinstein, A. and Wathieu, L. (2012). Go green! should environmental messages be so assertive? Journal of Marketing, (76) $1,95-102$.

Kumar, B.; Manrai, A. K., \& Manrai, L. A. (2017). Purchasing behaviour for environmentally sustainable products: A conceptual framework and empirical study. Journal of Retailing and Consumer Services, 34, 1-9. https://doi.org/10.1016/i.jretconser.2016.09.004.

Lee, K. (2011). The green purchase behavior of Hong Kong young consumers: the role of peer influence, local environmental involvement, and concrete environmental knowledge,Journalof International Consumer Marketing, 1(23), 21-44.

Leonidou,L. C.; Leonidou, C. N., \& Kvasova, O. (2010). Antecedents and outcomes of consumer/environmentally friendly attitudes and behaviour. Journal of Marketing Management, 26(13-14), 13191344.

Lin, J. \& Lobo, A. \& Leckie, C. (2017). The role of benefits and transparency in shaping consumers' green perceived value, selfbrand connection and brand loyalty. Journal of Retailing and $\begin{array}{lll}\text { Consumer } & \text { Services. } & 35 .\end{array}$ 10.1016/j.jretconser.2016.12.011.

Luchs, M.G.; Naylor, R.W.; Irwin, J.R. and Raghunathan, R. (2010). The sustainability liability: potential negative effects of ethicality on product preference, Journal of Marketing, (74) 5, 18-31.

Mei, O.J. \& Ling, K.C. \& Piew, T.H. (2012). The antecedents of green purchase intention among Malaysian consumers. Asian Soc. Sci., 8, 248-263.

Mohajan, H.K. (2012). Green Marketing is a Sustainable Marketing System in the Twenty First Century, International Journal of Management and Transformation, 6(2): 23-39. 
Moser, A.K., (2016). Consumers' purchasing decisions regarding environmentally friendly products: an empirical analysis of German consumers. J. Retail. Consum. Serv. 31, 389-397.

Norazah, M.S. (2013). Young consumer ecological behaviour: effects of environmental knowledge, healthy food, and healthy way of life with the moderation of gender and age, Management of Environmental Quality: An International Journal, (24) 6, 726737.

Park, J. O., \& Sohn, S.-H. (2018). The role of knowledge in forming attitudes and behavior toward green purchase. Social Behavior and Personality: An international journal, 46(12), 1937-1954.

Phau, I. and Ong, D. (2007). An investigation of the effects of environmental claims in promotional messages for clothing brands, Marketing Intelligence \& Planning, (25) 7, 772-788.

Punyatoya, P. (2015). Effect of perceived brand environmentfriendliness on Indian consumer attitude and purchase intention: An integrated model. Marketing Intelligence \& Planning. (33). 258-275. 10.1108/MIP-04-2013-0069.

Rand Corporation (2004). Consumer power, available at: www.rand.org/scitech /stpi/ourfuture/Consumer/index.html.

Rangkuti, R. R., \& Sulistyawati, E. (2014). Pengaruh social influnence dan lifestyle terhadap niat membeli pada carrefour, E-jurnal Manajemen Universitas Udayana. 3(2), 351-365.

Raska, D., \& Shaw, D. (2012). When is going green good for company image?, Management Research Review, 35(3), 326-347.

Rezai, G., \& Kit Teng, P. \& Mohamed, Z. \& Shamsudin, M. (2013). Is it easy to go green? Consumer perception and green concept. American Journal of Applied Sciences. 10. 793-800. 10.3844/ajassp.2013.793.800.

Rios, F.J.; Martinez, T.L.; Moreno, F.F. and Soriano, P.C. (2006). Improving attitudes toward brands with environmental associations: an experimental approach, Journal of Consumer Marketing, 1(23), 26-33. 
Rios, F.J.; Martinez, T.L.; Moreno, F.F. and Soriano, P.C. (2006). Improving attitudes toward brands with environmental associations: an experimental approach, Journal of Consumer Marketing, 1(23), 26-33.

Singhal, A., \& Malik, G. (2018). The attitude and purchasing of female consumers towards green marketing related to cosmetic industry. Journal of Science and Technology Policy Management. ahead-of-print. 10.1108/JSTPM-11-2017-0063.

Soonthonsmai, V. (2007). Environmental or green marketing as global competitive edge: Concept, synthesis, and implication. EABR (Business) and ETLC (Teaching) Conference Proceeding, Venice, Italy.

Suki, N. (2016). Green product purchase intention: impact of green brands, attitude, and knowledge, British Food Journal, 12(118), 2893-2910.

Tseng, S.-C. (2013) A framework identifying the gaps between customers 'expectations and their perceptions in green products. Journal of Cleaner Production. (59), 174-84.

Ulun Akturan, (2018). How does greenwashing affect green branding equity and purchase intention? An empirical research, Marketing Intelligence \& Planning, (36) 7, 809-824.

Vernekar, S.S., \& Wadhwa, P. (2011). Green Consumption an Empirical Study of Consumers Attitudes and Perception regarding EcoFriendly FMCG Products, with special reference to Delhi and NCR Region.

Wang, H. \& Ma, B., \& Bai, R. (2019). How Does Green Product Knowledge Effectively Promote Green Purchase Intention? Sustainability. (11). 1193. 10.3390/su11041193.

Wolfe, K.L. \& Shanklin, C.W. Environmental practices and management concerns of conference center administrations. Journal of Hospitality and Tourism Research, 25(2), 209-216. 
Wolsink, M. (2007). Wind power implementation: the nature of public attitudes: equity and fairness instead of 'back yard motives, Renewable and Sustainable Energy Reviews, 6(11), 1188-1207.

Wolsink, M. (2007). Wind power implementation: the nature of public attitudes: equity and fairness instead of 'back yard motives, Renewable and Sustainable Energy Reviews, 6(11), 1188-1207.

Yadav, R., \& Pathak, G. S. (2016). Intention to purchase organic food among young consumers: evidences from a developing nation. Appetite, 96, $122 \quad-128, \quad$ Available from: https://doi.org/10.1016/j.appet.2015.09.017

Yang, Y., \& Zhao, X. (2019). Exploring the relationship of green packaging design with consumers' green trust, and green brand attachment. Social Behavior and Personality: An international journal, 47(8), e8181. 


\section{تأثيرالمعرفة بالعلامة التجارية الخضراء والثقة في العلامة التجارية الخضراء على نية المستهلكين للشراء \\ د. نيفين محمد الصغير أحمد رجب سيد \\ د. هببة حسن صادق \\ ملخص البحث باللغة العربية}

في الآونة الأخيرة، تلقت العلامات التجارية الصديقة للبيئة (EF) اهتماما كبيرا من الشـركات التي تسعى للحصول على ميزة

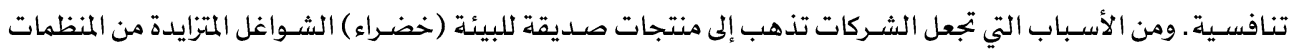

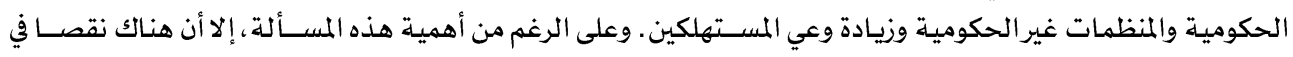

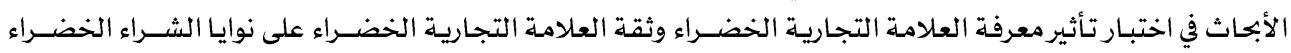

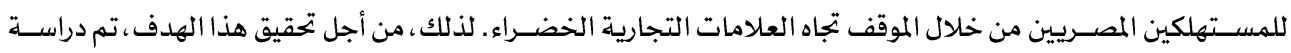

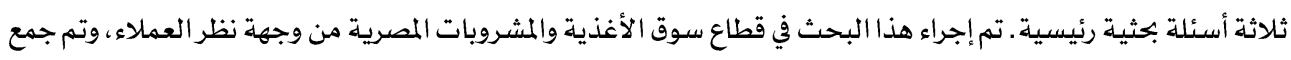

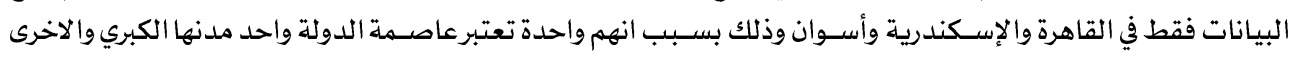

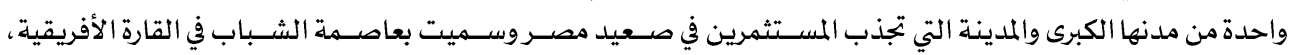

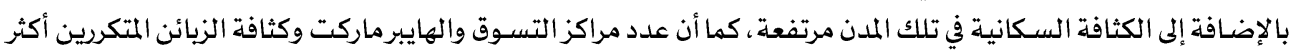

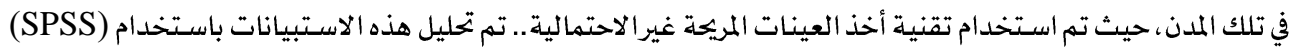

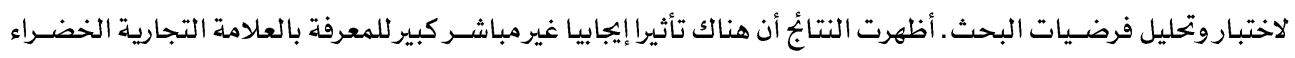

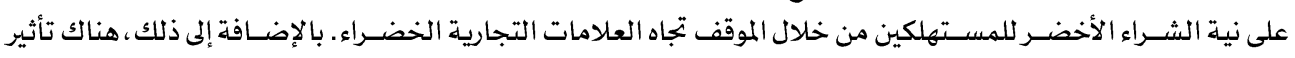
إيجابي مباشر كبير لثقة العلامة التجارية الخضراء على نية الشراء الخضر ملفراء للمستهلكين.

الكلمات الدالة : المعرفة الخضراء، ثقة بالعلامة الخضراء، الموقف تجاه العلامات التجارية الخضراء، نية الشراء الأخضر، الخراء

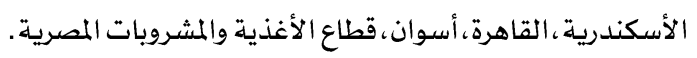

\section{Suggested Citation according to APA Style}

Sayed, A.R.; El Saghier, N.M.; Sadek, H. H. (2021). The Effect of Green Brand and Trust on Consumers' Purchasing Intention: The Mediation Role of Attitude Towards Green Brands Egypt Case. Journal of Alexandria University for Administrative Sciences, Faculty of Commerce, Alexandria University 58(5), 61 - 101. 